Global Conferences Series:

Social Sciences, Education and Humanities (GCSSSEH), Volume 6, 2020

International Conference Fakultas Tarbiyah dan Keguruan Universitas Islam Negeri Imam Bonjol Padang (ICFTKUINIBP) 2020

DOI: https://doi.org/10.32698/icftk400

\title{
Independent Learning A New Paradigm Concept inLearning Management in Indonesia
}

\section{Merdeka Belajar Sebagai Konsep Paradigma Baru dalam Manajemen Pembelajaran di Indonesia}

\author{
Zulvia Trinova ${ }^{a}$, Nini $^{a}$, Inda Fitri ${ }^{a}$ \\ ${ }^{a}$ Universitas Islam Negeri Imam Bonjol, Padang, Indonesia \\ E-mail: zulviatrinova@uinib.ac.id
}

\begin{abstract}
Independent learning is a policy of the Minister of Education and Culture since January 24, 2020, which contains regulations on university cooperation in forming new study programs. This type of research is descriptive analytic whose purpose is to make a systematic description of the facts and relationships between the phenomena being investigated. Independent learning-independent campus is carried out well by implementing learning management, such as: (1) student turnover, (2) job training, (3) helping someone who teaches, (4) experimenting in their field, (5) social work (6) self-employed, (7) independent learning, and (8) real work lectures. The improvements to the credit rules for SKS on an independent campus are: (1) In the past, students had limitations and were not given the independent learning outside their fields on their campus; (2) SKS load outside the campus is small and does not match the students who are involved in the field; (3) In several existing campuses, the movement between one student and another student to a different campus resulted in their late graduation.
\end{abstract}

Keywords:Independent learning, independent campus, new paradigm, learning management

\section{PENDAHULUAN}

Kemerdekaan merupakan sebuah kebebasan. Sikap bebas untuk bisa berkreasi, berpendapat, mengeluarkan ide cemerlang dan sebagainya, sehingga semua pihak dapat hidup dengan rukun dan damai tanpa ad

anya perselisihan (Nuna, M., \& Moonti, R. M., 2019; Hamdani, M., 2018). Menurut pendapat lain kemerdekaan adalah saat mampu mandiri, berdiri dengan berani, hidup sejahtera dan bisa mengelola dengan penuh, baik kebutuhan maupun sumber daya manusia tanpa paksaan dan ketergantungan dengan orang/bangsa lain (Musman, A., 2020; Putri, T. A., \& Nasution, M. I. S.).

Pada kampus yang belum menerapkan konsep merdeka belajar sistem perkuliahannya menggunakan sistem tatap muka langsung. Proses belajar mengajar yang dahulunya kampus merupakan sebuah lembaga pendidikan yang mana di dalam kampus tersebut proses belajar mengajarnya berlangsung secara tatap muka di dalam kelas (Kresnapati, P., \& Setyawan, D. A., 2020; Priatmoko, S., \& Dzakiyyah, N. I., 2020). Pada proses pembelajaran ini dosen adalah salah satu sumber utama dalam pembelajarannya, sehingga menjadikan mahasiswa menjadi mahasiswa yang bergantung kepada dosennya yang membuat mereka menjadi mahasiswa yang tidak bisa memecahkan masalah secara mandiri (Sadikin, A., \& Hamidah, A., 2020; Santyasa, I. W., 2018, May).

Kampus yang belum menerapkan konsep merdeka belajar menerapkan sistem pembelajaran SKS, di mana proses perkuliahan harus dilakukan di dalam kelas pada kampus tersebut. Pada sistem perkuliahan ini mahasiswa menjadi kurang kemerdekaan untuk belajar. Jadi yang dimaksud merdeka belajar pada sebuah kampus adalah memberi kebebasan untuk belajar dan otonomi kepada kampus (Arifin, S., \& Muslim, M. O. H., 2020).

Copyright (C2020, the Authors. Published by Redwhite Press. 
Di samping itu juga kebebasan birokratisasi, maksudnya para dosen diberikan kebebasan dari birokrasi yang berbelit di kampus, begitu juga dengan mahasiswa diberikan kebebasan untuk memilih bidangnya sesuai dengan keinginan mereka dengan adanya kerjasama antar kampus ini (Antari, N. N. W., 2017; Harningsih, A., 2019). Seperti dalam hal menyusun kurikulum antar lembaga pendidikan, praktik kerja lapangan bagi mahasiswa, dan adanya daya tampung kerja bagi mahasiswa. Dengan keadaan yang kurang memberikan kebebasan kepada dosen dan mahasiswa ini muncullah sebuah kebijakan baru dari Menteri Pendidikan dan Kebudayaan RI Kabinet Indonesia Maju yang disebut kampus merdeka. Kerja sama dengan organisasi bisa mencakup penyusunan kurikulum, praktik kerja, dan penyerapan lapangan kerja (Tohir, M., 2020; Wahyuni, S., 2020).

Kampus merdeka bertujuan agar mahasiswa memiliki berbagai keilmuan sehingga nantinya berguna bagi mahasiswa dalam mencari pekerjaan (Putriawan, N., 2019; Diah, F. A. F., 2020). Konsep kampus merdeka ini memberikan kebebasan dan kesempatan untuk mahasiswa memilih mata kuliah yang akan mereka ambil pada suatu semester tanpa harus mengambil sesuai dengan beban kuliah per semesternya, sehingga mahasiswa lebih leluasa untuk belajar. Adanya konsep belajar merdeka tentunya bertujuan untuk memberikan keleluasaan kepada mahasiswa untuk belajar di luar kampus. Harapannya dengan diterapkannya merdeka belajar di kampus adalah untuk menjadikan mahasiswa itu menjadi calon pemimpin berkualitas di masa yang akan datang dan untuk mengikuti arus perubahan serta kebutuhan mahasiswa akan link and match nantinya (Rahardja, U., Lutfiani, N., Lestari, A. D., \& Manurung, E. B. P., 2019).

Kebijakan baru yang dibuat oleh Menteri Pendidikan dan Kebudayaan RI adalah pada poin pertama dalam hal membuka program studi baru bagi kampus (Siregar, N., Sahirah, R., \& Harahap, A. A., 2020). Program tersebut membolehkan bekerjasama bagi lembaga pendidikan, dalam hal ini universitas dengan universitas yang lainnya yang memiliki Top 100 QS World University Ranking. Bagi lembaga pendidikan diberikan kesempatan dan diberi kemudahan membuka program studi baru dengan syarat telah terakreditasi A dan B.

Pada poin kedua konsep merdeka belajar ini adalah dalam hal penjaminan mutu untuk akreditasi lembaga pendidikan (Suci, A., Maryanti, S., Van FC, L. L., \& Yandra, A., 2020). Kampus diberikan kemudahan dalam mengurus akreditasi kampusnya dengan tetap menjalin kerjasama dengan industri, organisasi profesi yang memiliki keahlian yang sama dengan mereka, dan dengan anggota masyarakat.

Poin ketiga adalah memberi keleluasaan pada Perguruan Tinggi Negeri Badan Layanan Umum (PTN BLU) dan Satuan Kerja (Satker) menjadi sebuah Perguruan Tinggi Negeri Badan Hukum (PTN-BH). Kampus merdeka yang telah dibentuk tersebut, akan dikeluarkan akreditasinya dengan bantuan pemerintah dengan cara tidak mempersulit pengurusannya. Ketentuan administrasi yang telah ditetapkan untuk PTN BLU dan Satker tersebut tidak bergantung pada penilaian yang telah ada sebelumnya (akreditasi kampus).

Poin keempat tentang adanya kebebasan belajar mahasiswa 3 semester di luar kampus (Siregar, N., Sahirah, R., \& Harahap, A. A., 2020). Aturan ini memiliki dampak yang baik untuk mahasiswa yang diberi kebebasan belajar di luar prodi dan perguruan tinggi tempat mereka kuliah. Urusan mahasiswa lainnya pada merdeka belajar ini adalah magang yang dilakukan di industri-insustri sesuai dengan keahlian mahasiswa, Exchange Students Program, pengabdian masyarakat, tergabung dalam kegiatan proyek desa seperti PNPM, wiraswasta, penelitian, pembelajaran yang dilakukan secara mandiri, maupun pelaksanaan PPL pada daerah terisolir, dan aktivitas lainnya yang ditentukan oleh kampus. Aktivitas ini hanya berlaku pada mahasiswa bidang sosial dan eksak, sedangkan bidang kesehatan tidak berlaku aturan ini.

Tujuan dari terciptanya program kampus merdeka ini adalah agar mahasiswa dapat bekerja sesuai dengan permintaan lapangan kerja. Untuk itu, lembaga pendidikan tinggi harus bisa menyusun dan melakukan kegiatan belajar mengajar yang kekinian, sehingga tercapai tiga unsur dalam pendidikan yaitu unsur kognitif, afektif dan psikomotor.

Strategi dari merdeka belajar dan juga kampus belajar di antaranya memiliki penilaian, ada yang baik dan ada juga yang menilai buruk dari mahasiswa maupun rakyat sipil lainnya (Sherly, S., Dharma, E., \& Sihombing, H. B., 2020; Hadiwinarto, H., 2020). Hal ini disebabkan karena adanya aktivitas yang dilakukan di luar kampus, seperti adanya kelas di café. Adanya aktivitas ini dapat menciptakan manusia yang berkualitas dalam ilmunya atau keahliannya, sehingga memajukan mutu dari lembaga pendidikan tersebut, khususnya untuk program strata satu (S.1) tercipta mahasiswa yang bermutu bagus dan berkualitas baik.

Adanya lembaga pendidikan yang bermutu baik, membuat lembaga pendidikan tinggi tersebut dapat memenuhi kebutuhan masyarakat melalui penyesuaian program dan aktivitas kampus dengan kebutuhan dunia kerja nantinya. Harapannya lembaga pendidikan tinggi ini dapat bersaing dengan ide-ide baru pada semua tingkat pendidikan lainnya. Untuk itu, lembaga pendidikan, khususnya kampus dianjurkan untuk memiliki metodik khusus sehingga dapat memperbaiki diri lebih baik secara gesit dan dengan mudah. Kenyataannya, lembaga pendidikan pada masa sekarang belum sepenuhnya dilirik dalam hal perubahan- 
perubahan yang terbaru. Padahal sebuah perguruan tinggi harus memiliki ide-ide untuk perubahan di masa yang akan datang (Direktorat Jenderal Pendidikan Tinggi Kementerian Pendidikan dan Kebudayaan, 2020).

Aplikasi dari merdeka belajar dan kampus merdeka adalah dapat memberikan keleluasaan atau kebebasan kepada mahasiswa untuk dapat menyesuaikan diri dengan dunia luar lainnya. Ke depannya, mahasiswa dapat belajar menyesuaikan diri untuk hidup yang lebih baik secara otomatis. Program ini menjadikan mahasiswa lebih siap dan mapan dalam mencari lowongan pekerjaan yang dibutuhkannya (Direktorat Jenderal Pendidikan Tinggi Kementerian Pendidikan dan Kebudayaan, 2020).

Tujuan dari ditetapkannya merdeka belajar yaitu (1) memajukan pelaksanaan aktivitas belajar di lembaga pendidikan tanpa tergantung pada perguruan tinggi lainnya dan berjalan secara mudah, dan (2) mewujudkan suasana interaksi antara dosen dan mahasiswa dalam kegiatan menuntut ilmu yang lebih baik, dengan memberikan keleluasaan kepada mahasiswa sesuai dengan kepentingannya (Direktorat Jenderal Pendidikan Tinggi Kementerian Pendidikan dan Kebudayaan, 2020).

\section{METODE}

Metode penelitian (research methods) adalah "langkah ilmiah untuk mendapatkan data dengan tujuan dan kegunaan tertentu (N.S. Sukmadinata, 2008). Adapun jenis penelitian dari penelitian ini adalah penelitian yang memaparkan secara analitik.

Penelitian deskriptif yang dimaksud adalah untuk menggambarkan atau mendeskripsikan satu variabel secara sistematis. Jadi penelitian deskriptif analitik menggambarkan penggunaan berbagai data historis untuk menggambar perbandingan (A. Furchan, 2004). Dapat dikatakan bahwa penelitian deskriptif merupakan penelitian yang berusaha mendeskripsikan suatu gejala, peristiwa yang terjadi pada saat sekarang atau masalah aktual. Penelitian deskriptif merupakan penelitian yang berusaha mendeskripsikan dan menginterpretasikan sesuatu, misalnya kondisi atau hubungan yang ada, pendapat yang berkembang, proses yang sedang berlangsung, akibat atau efek yang terjadi, atau tentang kecenderungan yang tengah berlangsung.

Deskriptif analitik dapat dikatakan sebagai suatu cara bagaimana suatu data ditampilkan agar informasi yang ditampilkan dapat secara jelas diterima oleh orang lain. Pada deskriptif analitik, suatu data biasanya ditampilkan dalam bentuk tabel dan grafik. Pemilihan penyajian data dalam bentuk tabel atau grafik disesuaikan dengan jenis data dan tujuan yang ingin dicapai (Suharsimi Arikunto, 1992). Menurut pendapat yang lain, metode deskriptif analitik merupakan metode penelitian yang menyajikan gambaran lengkap dengan mendeskripsikan peristiwa-peristiwa yang terjadi di kehidupan manusia (Unaradjan, D. D., 2019).

Metode yang bertujuan menggambarkan secara sistematis dan faktual tentang fakta-fakta serta hubungan antar variabel yang diselidiki dengan cara mengumpulkan data, mengolah, menganalisis, dan menginterpretasi data dalam pengujian hipotesis statistik disebut juga deskriptif analitik (Nana Sudjana, 2009).

Sumber data penelitian ini data primer dan data sekunder. Pengumpulan data menggunakan sumber primer dan sekunder. Sumber primer adalah sumber data yang langsung memberikan data kepada pengumpul data, dan sumber sekunder merupakan sumber tidak langsung memberikan data kepada pengumpul data.

Penelitian ini mengambil masalah atau memusatkan perhatian kepada masalah-masalah sebagaimana adanya saat penelitian ini dilaksanakan. Hasil dari penelitian ini selanjutnya diolah berdasarkan berbagai sumber bacaan terkini yang ada dan dianalisa untuk akhirnya diambil sebuah kesimpulan.

\section{HASIL DAN PEMBAHASAN}

\section{Konsep Kemerdekaan Akademik dalam Belajar}

Secara etimologi kata merdeka berasal dari bahasa Sansekerta maharddhika yang artinya rahib/biku atau keramat, sangat bijaksana/ alim. Kata merdeka menurut pendapat yang lainnya adalah kenyataan untuk tiap-tiap perseorangan atau masyarakat luas pada masa sekarang yang diberikan kebebasan untuk melakukan sesuatu hal. Jadi merdeka atau kemerdekaan merupakan sesuatu yang dibawa manusia sejak lahir sesuai dengan kondisi dan situasi tertentu. Namun kenyataan masih banyak individu yang belum memiliki kebebasan sepenuhnya dalam arti yang sesungguhnya masih terbelenggu dengan aturan-aturan yang ada di lingkungan mereka berada, walaupun secara tertulis. Kemerdekaan adalah merupakan kebebasan dari beban hidup dan kehidupan, idak ada ikatan yang mengekang, namun bisa sejalan beriringan.

Pemikiran kemerdekaan akademik diperkenalkan atau ditemukan oleh seorang filosof yang berasal dari negara Jerman yang bernama Wilhelm Von Humboldt pada tahun 1809. Pemikiran kemerdekaan akademik ini adalah pemikiran yang memberikan keleluasaan oleh kampus kepada mahasiswanya dalam hal 
menentukan jurusan yang mereka ingini, juga keleluasaan kepada pengajar atau dosen untuk mengembangan bidang keahliannya dengan mengajarkan mata kuliah sesuai dengan keahliannya.

Aturan kampus merdeka ini ke depannya menjadikan kampus-kampus yang ada di Indonesia dengan diberikannya tempat yang baik bagi mahasiswanya, sehingga nantinya mereka dapat bekerja sesuai dengan kebutuhan masyarakat pada masa depan. Selain itu, aturan ini juga memberikan kemudahan kepada kampus dalam hal penilaian kampusnya ke tingkat yang lebih baik, memberikan kebebasan kepada mahasiswa untuk bisa menambah ilmu di luar ruangan yang sudah ditentukan oleh kampus tempat mereka menimba ilmu, hak untuk menambah jurusan baru, dan murahnya menjadikan PTN Badan Layanan Umum (BLU) dan Satuan Kerja (Satker) ke PTN Badan Hukum (PTN BH).

Aturan-aturan yang telah ditetapkan ini termuat dalam Permendikbud No. 3 Tahun 2020 tentang Standar Nasional Pendidikan Tinggi. Ketentuan ini diaplikasikan oleh beberapa elemen yang terhubung yaitu perguruan tinggi, fakultas, program studi, mahasiswa, dan kerjasama antara berbagai pihak. Pengurus perguruan tinggi tersebut, harus dapat menjadi fasilitator untuk mahasiswa seperti:

a. SKS yang diambil adalah 2 semester dengan beban 40 SKS di luar kampus atau belajar di lapangan.

b. Dibolehkannya memilih SKS pada program studi yang tidak sama dengan kampus mahasiswa tersebut belajar dengan masa 1 semester dengan beban belajar 20 sks.

Untuk bagian fakultas, diwajibkan untuk:

a. Menyediakan sarana prasarana berupa absensi kehadiran mahasiswa per mata kuliah pada fakultas yang bisa dipilih mahasiswa untuk yang beda bidangnya

b. Menyediakan kelengkapan kerjasama (MoU/SPK) dengan prodi yang berbeda

Untuk bagian program studi, diwajibkan untuk:

a. Melengkapi bahan ajar dengan konep penerapan kampus merdeka

b. Menyediakan mahasiswa untuk belajar ilmu yang berbeda dalam kampus merdeka

c. Mengunjukkan suatu mata kuliah kepada mahasiswa yang aan diambilnya di luar bidangnya dan di luar kampusnya sambil menyediakan kelengkapan administrasi mahasiswanya

d. Melaksanakan mata kuliah yang sepadan dengan usaha belajar mengajar di luar bidang dan luar kampusnya

e. Menyiapkan mata kuliah yang sepadan untuk proses belajar mengajar di luar bidang dan di luar kampus dengan menggunakan aplikasi internet secara tidak langsung (daring) (Sudaryanto, 2020).

Untuk bagian mahasiswa, diwajibkan untuk:

a. Mengupayakan bersama dosen PA mereka mencari tahu informasi tentang program mata kuliah yang dipilih untuk dipelajari di luar bidangnya

b. Masuk ke dalam bidang yang berbeda dengan yang mereka ambil

c. Memenuhi kewajiban untuk belajar di luar bidangnya, bahkan juga ikut serta dalam pemilihan yang dilakukan oleh bidang yang berbeda tersebut bila mereka melakukannya

d. Mengikuti program kegiatan luar prodi sesuai dengan ketentuan pedoman akademik yang ada.

Untuk bidang yang dijalin kerjasamanya, diwajibkan untuk:

a. Melengkapi arsip kerjasama (MoU/SPK) kampus/fakultas/ bidangnya

b. Mengaplikasikan rencana bidang yang berbeda tersebut sama halnya dengan ketetapan pada arsip kerjasama (MoU/SPK) (Sudaryanto, 2020; 79-80).

Untuk para dosen harus dapat melakukan tri dharma perguruan. Para dosen secara realnya memiliki beban yang cukup berat, terutama dalam melakukan kewajibannya sebagai seorang dosen yang profesional yaitu melengkapi beban kerjanya sebagai seorang dosen dengan melakukan pengajaran, penelitian, dan pengabdian kepada masyarakat.

Jadi, aturan merdeka belajar-kampus merdeka akan terlaksana dengan baik apabila melakukan pembelajaran, seperti:

a. Pergantian mahasiswa

b. Pelatihan kerja

c. Membantu seseorang yang mengajar dalam bidang pengajaran

d. Percobaan dalam bidangnya

e. Pekerjaan sosial

f. Melakukan wiraswasta 


\section{g. Pembelajaran tersendiri \\ h. Kuliah kerja nyata}

Diberikannya kemudahan kepada kampus untuk membuka bidang yang baru membuat universitas tersebut harus mengikuti perubahan teknologi, sehingga nantinya dapat mengikuti dan mempelajari perubahan-perubahan yang terjadi secara cepat karena jika tidak mengikuti perkembangan yang ada, kampus tersebut akan tertinggal dengan kampus yang lainnya. Kampus-kampus yang mengikuti perkembangan yang ada akan hidup dan diminati oleh masyarakat luas karena pada nantinya mereka akan bersaing dengan kampus yang lainnya. Adanya prodi baru dapat memberi keleluasaan bagi mahasiswa untuk menentukan bidang yang akan mereka pelajari sesuai dengan kondisi zaman pada masa yang akan datang.

Adanya kampus merdeka ini yang sangat bermanfaat adalah mahasiswa yang belajar di kampus tersebut. Karena mahasiswa yang belajar di sana dapat belajar di luar bidang ilmunya dengan perpindahan kampus sesuai dengan yang mereka ingini. Untuk masa berikutnya mahasiswa dapat mengaplikasikan ilmu yang telah mereka peroleh di luar dan dalam kampus untuk dapat hidup di era persaingan untuk memperoleh pekerjaan nantinya. Penemuan UNESCO 5 juta mahasiswa di Negara-negara maju melakukan perpindahan kampus. Untuk program praktek lapangan mahasiswa banyak yang menyukainya. Kemendikbud pernah melakukan kebebasan 45 jam praktek lapangan sama dengan 1 SKS sehingga mahasiswa tidak dirugikan dalam mata kuliah yang sudah diambilnya.

Harapan Mendikbud adalah ingin melakukan pendidikan yang lebih baik ke depannya dan dapat bersaing bebas di luaran. Untuk itu kepada pemerintah untuk lebih memperhatikan para dosen dengan meringankan kewajibannya dalam bidang administratif, sehingga para dosen dapat meningkatkan ilmunya yang lebih tinggi yang nantinya akan melahirkan generasi yang maju, efek dari dosen yang mengajarkan memiliki ilmu yang memadai di bidangnya.

\section{Kebijakan Kampus yang menerapkan Merdeka Belajar di Indonesia}

Aplikasi konsep ini adalah para mahasiswa diberi kebebasan dua semester belajar di luar bidangnya. Pada akhirnya, mahasiswa dapat lebih menyesuaikan diri dengan daerah dan pekerjaan yang akan mereka ambil nantinya. Dengan adanya perubahan ini, dapat melahirkan sebuah pemikiran baru dalam bidang pendidikan sehingga mahasiswa dapat menentukan mata kuliah yang baru nantinya.

Adapun perbaikan tata aturan pada kredit SKS pada kampus merdeka adalah:

a. Pada masa dahulu mahasiswa memiliki keterbatasan dan tidak diberi kebebasan untuk belajar di luar bidangnya di kampus mereka.

b. Beban SKS di luar kampus sedikit sekalu dan tidak sesuai antara mahasiswa yang terjun ke lapangan

c. Pada beberapa kampus yang ada, perpindahan antara mahasiswa yang satu dengan mahasiswa yang lainnya ke kampus yang berbeda mengakibatkan terlambatnya mereka diwisuda di kampusnya.

Perguruan Tinggi Negeri maupun swasta ada keleluasaan untuk melakukan kegiatan atau kebijakan membuka bidang lainnya yang baru. Hal-hal yang harus dipenuhi adalah PTN dan PTS yang menambah program baru wajib memiliki nilai A dan B, dan menjalin hubungan dengan kampus lain yang Top 100 QS World Universities.

a. Upaya perbaikan akreditasi dimudahkan

Upaya perbaikan akreditasi tidak dipersulit. Penilaian kampus dilakukan lima tahun sekali untuk masing-masing kampus yang ada. Aturan yang berlaku ini dapat diperbaiki secara langsung oleh kampus tersebut bagi kampus yang memiliki nilai akreditasi A atau B. Penilaian ini dilaksanakan oleh sebuah badan yang disebut BAN-PT. Apabila kampus tersebut memiliki kekurangan dan kecurangan dalam pelaksanaannya serta penurunan kualitas pembelajaran maka kampus tersebut tidak mengalami peningkatan dalam penilaian akreditasi kampusnya.

b. Hal-hal yang harus dipenuhi untuk berubah PTN-BH tidak dipersulit

Aturan yang dibuat pada kampus merdeka yaitu keleluasaan perguruan tinggi negeri Badan Layanan Umum (BLU) dan Satuan Kerja (Satker) berubah ke tingkat PTN Badan Hukum (PTN $\mathrm{BH}$ ) tidak dipersulit dan tidak dikaitkan dengan status kampusnya. Pada masa sekarang hanya kampus yang memiliki nilai A dapat berubah ke tingkat PTN BH. 
c. Adanya kebebasan belajar mahasiswa untuk belajar 3 semester di luar bidangnya dan perbaikan istilah SKS

Kampus yang mahasiswanya boleh memilih mata kuliah di luar bidangnya dan di luar kampusnya hak itu berlaku 2 semester atau sebanding dengan 40 sks. Mahasiswa diberi kebebasan untuk satu semester belajar di luar prodinya. Pemerintah menyatakan bahwa selama ini nilai SKS di luar kampus persentasenya sedikit sekali, sehingga mahasiswa tidak bisa mendapatkan sesuatu yang baru untuk menunjang profesinya. Ditambah lagi diberbagai universitas, perpindahan antara mahasiswa satu ke mahasiswa lain untuk kampus yang berbeda dalam mempraktekkan ilmu yang sudah mereka terima malahan mahasiswa tersebut tidak bisa diwisuda tepat waktu.

Masing-masing SKS dianggap kampus jam aktivitas bukan jam menuntut ilmu. Pemikiran yang sederhana dari kampus merdeka adalah bahwa mahasiswa hanya belajar untuk bidang yang sama saja. Sedangkan untuk konsep yang baru mahasiswa tidak hanya menuntut di kampus yang sama saja tetapi lebih menerapkan dan menimba ilmu di luar kampusnya dengan mempraktekkan ilmu-ilmu yang sudah mereka terima selama ini.

\section{SIMPULAN}

Adapun kesimpulan yang dapat diambil adalah bahwa aturan merdeka belajar-kampus merdeka terlaksana dengan baik apabila melakukan manajemen pembelajaran di Indonesia, seperti: (1) pergantian mahasiswa, (2) pelatihan kerja, (3) membantu seseorang yang mengajar dalam bidang pengajaran, (4) percobaan dalam bidangnya, (5) pekerjaan sosial (6) melakukan wiraswasta, (7) pembelajaran tersendiri, dan (8) kuliah kerja nyata.

Adapun perbaikan tata aturan pada kredit SKS pada kampus merdeka adalah: (1) Pada masa dahulu mahasiswa memiliki keterbatasan dan tidak diberi kebebasan untuk belajar di luar bidangnya di kampus mereka; (2) Beban SKS di luar kampus sedikit sekali dan tidak sesuai antara mahasiswa yang terjun ke lapangan; (3) Pada beberapa kampus yang ada, perpindahan antara mahasiswa yang satu dengan mahasiswa yang lainnya ke kampus yang berbeda mengakibatkan terlambatnya mereka diwisuda di kampusnya.

Ada dua saran terkait aplikasi konsep Merdeka Belajar-Kampus Merdeka. 1) Bagi pihak Kemendikbud, salah satu bentuk kegiatan pembelajaran yaitu pertukaran pelajar belum dapat dilakukan antar-PTN/PTS di Indonesia dalam lingkup sebidang/serumpun ilmu. Misalnya, mahasiswa S-1 Prodi belum bisa menjalani pertukaran pelajar dengan mahasiswa S-1 Prodi yang lainnya. Sejauh pengamatan peneliti, belum ada ketentuan dan kesepakatan antar-PTN/PTS terkait pertukaran pelajar sehingga perlu dilakukan pertemuan antar pimpinan PTN/PTS (baca: Rektor, Dekan, Kajur, dan Kaprodi terkait). 2) Bagi pihak PTN/PTS, delapan bentuk kegiatan pembelajaran sebagaimana disebutkan perlu ditangani secara profesional oleh seluruh unit terkait. Sinergitas kerja antarlembaga seharusnya tercipta harmonis sehingga dapat menghasilkan kualitas kegiatan pembelajaran Merdeka Belajar-Kampus Merdeka secara optimal.

\section{REFERENSI}

Antari, N. N. W. (2017). Pendidikan demokrasi melalui kegiatan kuliah industri di stmik stikom bali. Cendekia: Jurnal Studi Keislaman, 3(1), 107-116.

Arifin, S., \& Muslim, M. O. H. (2020). Tantangan Implementasi Kebijakan "Merdeka Belajar, Kampus Merdeka" pada Perguruan Tinggi Islam Swasta di Indonesia. Jurnal Pendidikan Islam Al-Ilmi, 3(1).

Arikunto. Suharsimi. (1992). Prosedur Penelitian: Suatu Pendekatan Praktik. Jakarta. Bina Aksara.

Diah, F. A. F. (2020). Membentuk Sikap Kemandirian, Kepemimpinan, dan Kedisiplinan melalui Kegiatan Kepramukaan di UKM Racana Yogi Praja Parang Garuda Universitas Widya Dharma Klaten Tahun2019/2020 (Doctoral dissertation, Universitas Widya Dharma Klaten).

Direktorat Jenderal Pendidikan Tinggi Kementerian Pendidikan dan Kebudayaan. 2020. Buku Saku Panduan Merdeka Belajar Kampus Merdeka. Jakarta. Direktorat Jenderal Pendidikan Tinggi Kemendikbud RI

Furchan. A. 2004. Pengantar Penelitian dalam Pendidikan. Yogyakarta: Pustaka Pelajar Offset.

Hadiwinarto, H. (2020, August). Best Practice Praktik Bimbingan dan Konseling di Luar Sekolah sebagai Model Merdeka Belajar. In Prosiding Seminar Nasional Bimbingan dan Konseling Universitas Negeri Malang (pp. 142-147). 
Hamdani, M. (2018). Urgensi akal dan implikasinya dalam mencapai tujuan pendidikan Islam: studi integratif Islam dan filsafat (Doctoral dissertation, UIN Sunan Ampel Surabaya).

Harningsih, A. (2019). Analisis Faktor-Faktor Yang Mempengaruhi Keputusan Mahasiswa Memilih Program Studi Di Perguruan Tinggi Dalam Perspektif Ekonomi Islam (Studi terhadap Mahasiswa Angkatan 2017, Fakultas Ekonomi dan Bisnis Islam Universitas Islam Negeri Raden Intan Lampung) (Doctoral dissertation, UIN Raden Intan Lampung).

Kresnapati, P., \& Setyawan, D. A. (2020). Analisis perkuliahan daring mahasiswa PJKR Universitas PGRI Semarang sebagai dampak pandemi covid 19. Edu Sportivo: Indonesian Journal of Physical Education, 1(1), 25-32.

Musman, A. (2020). Seni Mendidik Anak di Era 4.0: Segala Hal yang Perlu Anda Ketahui dalam Mendidik Anak di Era Milenial; Mewujudkan Anak Cerdas, Mandiri, dan Bermental Kuat. Anak Hebat Indonesia.

Nuna, M., \& Moonti, R. M. (2019). Kebebasan Hak Sosial-Politik Dan Partisipasi Warga Negara dalam Sistem Demokrasi di Indonesia. Jurnal Ius Constituendum, 4(2), 110-127.

Priatmoko, S., \& Dzakiyyah, N. I. (2020). Relevansi kampus merdeka terhadap kompetensi guru era 4.0 dalam perspektif experiential learning theory. At-thullab, 4(1), 1-15.

Putri, T. A., \& Nasution, M. I. S. Implementasi Trilogi Pendidikan Ki Hajar Dewantara Pada Smk Tamansiswa Di Kota Tebing Tinggi. Puteri Hijau: Jurnal Pendidikan Sejarah, 5(1), 84-100.

Putriawan, N. (2019). Persepsi Mahasiswa dalam Pembelajaran Manajemen Perkantoran serta Pengaruhnya terhadap Kesiapan Kerja Mahasiswa Pendidikan Ekonomi (Studi Kasus Mahasiswa Program Studi Pendidikan Ekonomi FKIP Unpas Angkatan 2015) (Doctoral dissertation, FKIP UNPAS).

Rahardja, U., Lutfiani, N., Lestari, A. D., \& Manurung, E. B. P. (2019). Inovasi Perguruan Tinggi Raharja Dalam Era Disruptif Menggunakan Metodologi iLearning. Jurnal Ilmiah Teknologi Informasi Asia, 13(1), 23-34.

Sadikin, A., \& Hamidah, A. (2020). Pembelajaran Daring di Tengah Wabah Covid-19:(Online Learning in the Middle of the Covid-19 Pandemic). Biodik, 6(2), 214-224.

Santyasa, I. W. (2018, May). Student Centered Learning: Alternatif Pembelajaran Inovatif Abad 21 untuk Menyiapkan Guru Profesional. In Quantum: Seminar Nasional Fisika, dan Pendidikan Fisika.

Sherly, S., Dharma, E., \& Sihombing, H. B. (2020, September). Merdeka Belajar: Kajian Literatur. In UrbanGreen Conference Proceeding Library (Vol. 1, pp. 183-190).

Siregar, N., Sahirah, R., \& Harahap, A. A. (2020). Konsep Kampus Merdeka Belajar di Era Revolusi Industri 4.0. Fitrah: Journal of Islamic Education, 1(1), 141-157.

Suci, A., Maryanti, S., Van FC, L. L., \& Yandra, A. (2020). Dilema Ex-Officio Terkait Pencegahan Korupsi Dan Penjaminan Mutu Di Perguruan Tinggi Swasta. Jurnal Penjaminan Mutu, 6(1), 1-14.

Sudjana. Nana. 2009. Penelitian dan Penilaian Pendidikan. Bandung. Sinar Baru Algensindo.

Sukmadinata. N. S. 2008. Metode Penelitian Pendidikan. Bandung. Remaja Rosdakarya

Tohir, M. (2020). Merdeka Belajar: Kampus Merdeka.

Unaradjan, D. D. (2019). Metode penelitian kuantitatif. Penerbit Unika Atma Jaya Jakarta.

Wahyuni, S. (2020). Strategi Penguatan Kapasitas Lembaga Pelatihan dalam Meningkatkan Kompetensi SDM Aparatur untuk Mewujudkan Learning Organization. BESTARI, 1(1), 32-46. 